\title{
Polymorphisms within RANKL and Osteoprotegerin Genes in Low Bone Mass among Postmenopausal Indonesian Women
}

\author{
Postmenopozal Endonezyalı Kadınlarda Düşük Kemik Kitlesindeki RANKL ve \\ Osteoprotegerin Genlerindeki Polimorfizmler
}

\footnotetext{
(D) Ignatio Rika Haryono, (D) Angela Tulaar*, (D) Herawati Sudoyo**, (D) Ambrosius Purba***, (D) Murdani Abdullah****, (D) Sri Widia Jusman*****, (D) Andri Lubis******, (D) Ermita Ibrahim Ilyas*******

Universitas Katolik Indonesia Atma Jaya Faculty of Medicine, Department of Physiology, Jakarta, Indonesia *Universitas Indonesia-dr. Cipto Mangunkusumo General Hospital, Clinic of Physic and Rehabilitation, Jakarta, Indonesia **Eijkman Institute for Molecular Biology, Jakarta, Indonesia

***Padjadjaran University Faculty of Medicine, Department of Physiology, Bandung, Indonesia ****Universitas Indonesia-Dr. Cipto Mangunkusumo General Hospital, Clinic of Internal Medicine Division of Gastroenterology, Jakarta, Indonesia $* * * * *$ Universitas Indonesia Faculty of Medicine, Department of Biochemistry and Molecular Biology, Jakarta, Indonesia $* * * * *$ Universitas Indonesia-Dr. Cipto Mangunkusumo General Hospital, Clinic of Orthopaedic and Traumatology, Jakarta, Indonesia $* * * * * * *$ Universitas Indonesia Faculty of Medicine, Department of Medical Physiology, Jakarta, Indonesia
}

\section{Abstract}

Objective: Prior studies have shown that receptor activator of nuclear factor-B ligand (RANKL) and osteoprotegerin (OPG) have an essential role in bone remodeling and osteoporosis. This study aimed to investigate the association between RANKL (TNFSF11) and OPG (TNFRSF11B) genes' polymorphisms with low bone mineral density (BMD) in Indonesian postmenopausal women.

Materials and Methods: Sixty postmenopausal women aged between 50-65 years were eligible. The BMD was measured by using dualenergy X-ray absorptiometry. The genotypes of TNFSF11 and TNFRSF11B were obtained by polymerase chain reaction-restriction fragment length polymorphisms and DNA sequencing methods. Three single nucleotide polymorphisms (SNPs) from TNFSF11 (-290C>T, -643C $>$ T, $-693 \mathrm{G}>\mathrm{C})$ and from TNFRSF11B $(163 \mathrm{~A}>\mathrm{G}, 950 \mathrm{~T}>\mathrm{C}, 1181 \mathrm{G}>\mathrm{C})$ were selected. The association between alleles distribution and BMD was computed using chi-square or Fischer's exact test. Multiple logistic regression was used to analyze between all SNPS and BMD at bone sites. Significance was set at $p<0.05$.

Results: Most subjects had lower BMD (83.3\%). Characteristics of subjects between healthy and low BMD were comparable (all $p>0.05)$. The distribution of genotypes and alleles in TNSSF11 and TNFRSF11B between healthy and low BMD were not significantly different (all p>0.05). There was no association between SNPS of TNFSF11 and TNFRSF11B with BMD at all bone sites (all p>0.05).

Conclusion: The present study suggests that TNFSF11 and TNFRSF11B gene polymorphisms are not associated with BMD in Indonesian postmenopausal women aged between 50-65 years old.

Keywords: Bone mineral density, RANKL gene, OPG gene, polymorphism, postmenopause

\section{Öz}

Amaç: Reseptör aktivatör nükleer faktör-B ligandı (RANKL) ve osteoprotegerinin (OPG) kemik yeniden modelleme ve osteoporozda önemli bir rolü olduğu gösterilmiştir. Bu çalışmada, Endonezya menopoz sonrası kadınlarda düşük kemik mineral yoğunluğu (KMY) ile RANKL ve OPG genlerinin polimorfizmleri (sırasıyla TNFSF11 ve TNFRSF11B) arasındaki ilişkinin araştıılması amaçlanmıştır.

Gereç ve Yöntem: Elli - altmış beş yaş arası 60 postmenopozal kadın uygun bulundu. KMY, çift-enerjili X-ısını absorpsiyometrisi kullanılarak ölçülmüştür. TNFSF11 ve TNFRSF11B'nin genotipleri polimeraz zincir reaksiyonu-kısıtlama fragman uzunluğu polimorfizmleri ve DNA dizileme yöntemleri ile elde edildi. TNFSF11'den (-290C> T, -643C> T, -693G>C C) ve TNFRSF11B'den (163A>G, 950T>C, 1181G>C) üç tek nükleotid polimorfizmleri (SNP) seçildi. Allel dağılımı ile KMY arasındaki ilişki ki-kare veya Fischer kesin testi kullanılarak hesaplandı. Kemik bölgelerindeki tüm SNP'leri ve BMD’yi analiz etmek için çoklu lojistik regresyon kullanıldı. Anlamlılık p<0,05 olarak ayarlandı.

Bulgular: Çoğu birey daha düşük KMY'ye $(\% 83,3)$ sahipti. Sağlıklı ve düşük KMY arasındaki bireylerin özellikleri karşılaştıılabilir bulundu (hepsi p>0,05). TNSSF11 ve TNFRSF11B'de genotiplerin ve allellerin sağlıklı ve düşük KMY'ler arasındaki dağılımı anlamlı olarak farklı değildi (hepsi p>0,05). Tüm kemik bölgelerinde TNFSF11 ve TNFRSF11B'nin SNP'leri ile KMY arasında ilişki yoktu (hepsi p>0,05).

Address for Correspondence/Yazışma Adresi: Ignatio Rika Haryono MD, Universitas Katolik Indonesia Atma Jaya Faculty of Medicine, Department of Physiology, Jakarta, Indonesia Phone: +62 0216693168 E-mail: rika_haryono@yahoo.com ORCID ID: orcid.org/0000-0002-4057-4581 Received/Geliş Tarihi: 03.12.2018 Accepted/Kabul Tarihi: 29.01.2019

${ }^{\circ}$ Copyright 2019 by the Turkish Osteoporosis Society

Turkish Journal of Osteoporosis published by Galenos Yayınevi. 
Sonuç: Bu çalışma, 50-65 yaşlarındaki Endonezyalı postmenopozal kadınlarda TNFSF11 ve TNFRSF11 gen polimorfizmlerinin BMD ile ilişkili olmadığını düşündürmektedir.

Anahtar kelimeler: Kemik mineral yoğunluğu, RANKL geni, OPG geni, polimorfizm, postmenopoz

\section{Introduction}

The prevalence of low bone mass worldwide is high and varies between countries. In industrialized countries, the prevalence of osteoporosis ranged from $9 \%$ to $38 \%$ (1). In developing countries, prevalence of osteoporosis is comparable. The data from Indonesian Osteoporosis Society in 2007 showed that the number of elderly women with osteopenia in Indonesia was $90 \%$ and osteoporosis was about $32.3 \%$ of the total of the Indonesian population (2). The Indonesian National Statistics Bureau and the Indonesian Ministry of Health reported that the number of women with osteopenia and osteoporosis accounts for 9.6 million and 2.2 million in 2012-2013 (3,4). This number will continue to increase as prevalence of osteoporosis worldwide increases.

Low estrogen level plays an important role in the pathophysiology of low bone mineral density. Estrogen affects osteoclast and osteoblast activities, notable cells that regulate bone remodeling process. Estrogen increases osteoblast activity resulting in bone formation, whereas low estrogen increases osteoclast activity resulting in bone resorption (5). At the molecular level, bone remodeling involves receptor activator of nuclear factor-кB ligand (RANKL, a membrane protein and a member of tumor necrosis factor [TNF] superfamily), RANK (osteoclast cell-surface receptor that binds to RANKL), and osteoprotegerin (OPG, a TNF superfamily and competitive inhibitor of RANK). RANKL is expressed by osteoblast on the cell surface. Formation of the RANK-RANKL complex initiates activation and maturation of osteoclasts, leading to bone resorption. Otherwise, the formation of the OPG-RANKL complex inhibits activation and maturation of osteoclast, inducing bone formation $(6,7)$. Results from prior studies showed estrogen improved OPG production and accelerated osteoclast apoptosis. Therefore, lack of estrogen can attenuate bone formation and increase bone resorption resulting in low bone mass $(8,9)$.

Specific genes encode RANKL and OPG and are associated with osteoporosis genetic susceptibility $(10,11)$. TNF ligand superfamily member 11 (TNFSF11) gene encodes RANKL while TNF receptor superfamily member 11B (TNFRSF11B) gene encodes OPG $(12,13)$. Gene polymorphisms in osteoporosis are strongly influenced by race and ethnicity and are related to bone density on different skeletal sites $(14,15)$. A study in Poland reported -643C>T RANKL gene was associated with osteoporosis development whereas study in Slovak found 245T>G OPG gene increased risk of osteoporotic fractures $(16,17)$. Sassi et al. (18) demonstrated the relationhip between -643 RANKL gene and osteoporosis risk in postmenopausal Tunisian women. No studies have been carried out on the TNFSF11 and TNFRSF11B gene polymorphisms and their association with BMD sites in the Indonesian population. Therefore, the purpose of this study is to identify the polymorphism and its relationship with BMD at different skeletal sites in postmenopausal women in Indonesia.

\section{Materials and Methods}

\section{Subjects}

A cross-sectional study involved sixty women according to the eligibility criteria: female, age between 50-65 years, experiencing postmenopausal symptoms for at least 12 months, and Indonesian native. Participants were excluded if they used medication affecting bone mass, smoked, drank alcohol, or had a disease associated with low BMD (thyroid disease, chronic renal failure, diabetes mellitus, etc.). There was no family relationship among the participants.

All study participants agreed to be involved in the study by signing informed consent forms. The study was approved by the Research Ethics Committee of the Faculty of Medicine, Universitas Indonesia and Cipto Mangunkusumo Hospital (Protocol number: 679/UN2.F1/ETIK/2014). All procedures of this study were implemented according to the Declaration of Helsinki guidelines.

\section{Measurements}

Measurements of height and weight were performed. Height was measured using a wall-mounted stadiometer in the standing position without footwear. Height was reported in $\mathrm{cm}$ with $0.1 \mathrm{~cm}$ precision. Body height was measured using a portable digital scale (SECA, Robusta 813, Germany) with subjects in minimal clothes. Weight was reported in $\mathrm{kg}$ with 0.1 $\mathrm{kg}$ precision. Body mass index $\left(\mathrm{kg} / \mathrm{m}^{2}\right)$ is calculated by dividing weight $(\mathrm{kg})$ with height $(\mathrm{m})$ square.

\section{Dual X-ray Absorptiometry and Radiography Examination}

Bone mineral density was assessed using a standard DXA (Lunar Prodigy DF \pm 301251 , GE Healthcare, USA). The equipment was regularly calibrated. The DXA examination was performed by experts according to the standard procedure from the International Society for Clinical Densitometry. Bone mass density of the bone sites most susceptible to fracture were presented. Bone mineral density was expressed in grams per $\mathrm{cm} 2\left(\mathrm{~g} / \mathrm{cm}^{2}\right)$. According to the category by the WHO for BMD results, participants were classified as normal if T score > -1 SD, osteopenia if T score between -1 and -2.4 SD, and osteoporosis if $T$ score $\leq-2.5$ SD (19). For statistical purposes, osteopenia and osteoporosis were combined in one group denominated as "low BMD". Subjects were diagnosed as "low BMD" if they had low BMD at least on one site. 


\section{Genotyping}

Genomic DNA was obtained by extracting peripheral blood leucocytes using salting-out methods (20). The presence of TNFSF11 and TNFRSF11B gene was obtained from genbank (Acc No. NG_008990 for TNFSF11, Acc No. NO_012202 for TNFRSF11B). Three SNPs from TNFSF11 gene were selected as reported by previous studies: SNPs -290C $>T,-643 C>T$ and $-693 G>C$; and three SNPs from TNFRSF11B gene: SNPs 163A>G, $950 \mathrm{~T}>\mathrm{C}$, and $1181 \mathrm{G}>\mathrm{C}(21-23)$. The SNPs was identified using BioEdit software $\mathbf{7 7 . 0 . 0}$. Primers of TNFSF11 gene (SNPS $-290 \mathrm{C}>\mathrm{T},-643 \mathrm{C}>\mathrm{T}$, and $-693 \mathrm{G}>\mathrm{C}$ ) and TNFRSF11B gene (SNPs $163 \mathrm{~A}>\mathrm{G}, 950 \mathrm{~T}>\mathrm{C}$, and $1181 \mathrm{G}>\mathrm{C}$ ) are listed in Table 1.

The genotype was screened using polymerase chain reactionrestriction fragment length polymorphism (PCR-RFLP). The PCRRFLP was performed using the KAPA Tag Extra Hostart PCR $\mathrm{kit}^{\circledR}$ mix (KAPA Biosystem, USA). A total of $25 \mu \mathrm{L}$ PCR reactions were performed using $0.4 \mathrm{pmol} / \mathrm{L}$ primers, $3.5 \mathrm{mM} \mathrm{MgCl} 20.4$ $\mathrm{mM}$ dNTP Mix, and 0.05 units/ $\mu \mathrm{L}$. The RFLP was carried out by using specific restriction enzymes for the digestion process of PCR products. The digestion process was completed by adding 6 units of specific restriction enzymes and then incubated at a certain temperature and time. The restriction enzymes, temperature, and duration of incubation for all SNPs were summarized in Table 1. Sequencing was carried out following RFLP to confirm that DNA fragment was in accordance with the expected fragment.

\section{Statistical Analysis}

Numerical data were presented as mean \pm standard deviation (SD), while categorical data as frequencies and percentage

(\%). Results of BMD were presented in $\mathrm{g} / \mathrm{cm}^{2}$ and according to the t-score. Chi-square or Fischer exact test was used to analyze distribution of the allele between healthy and low BMD. Multivariate logistic regression was applied to analyze the association between SNPs and BMD of each bone sites. A $p$ value $<0.05$ was considered significant. The statistical analysis was performed using the SPSS ver. 17.0 (SPSS Inc., Chicago, IL, USA).

\section{Results}

Characteristics of the participants consisted of age, weight, height, and BMI, as presented in Table 2. Bone mineral density of four bone sites (L1-L4, femoral neck, total femur, and third distal radius) were selected as most vulnerable sites to fracture. Fifty subjects (83.3\%) were diagnosed as having low BMD in which most of them (82\%) had low BMD on more than one bone site (82\%). Low BMD at single site was found on lumbar and radius.

Genotype and allele frequency of the three SNPs in the RANKL and OPG gene in healthy and low BMD subjects are shown in Table 3. Genotype homozygous dominant tends to be more prominent in TNFRSF11B whereas genotype heterozygous and homozygous recessive in TNFSF11. However, none of the distributions of the genotypes and allele in the RANKL and OPG genes were significantly different (all $p>0.05$ ).

Further analysis was performed to examine the correlations between BMD of bone sites and SNPs of genes using a multivariate logistic regression. The BMD of bone sites had no correlation with each SNPs in both genes (all $p>0.05$ ). Adjusted regression showed no correlation between BMD of bone sites and all SNPs of both genes (all p>0.05) (Table 4).

\section{Table 1. Procedures of genotyping for TNFSF11 and TNFRSF11B polymorphisms}

\begin{tabular}{|c|c|c|c|c|}
\hline SNPS & Direction & Primers & $\begin{array}{l}\text { Restriction } \\
\text { enzyme }\end{array}$ & $\begin{array}{l}\text { Incubation } \\
\text { period/ } \\
\text { temperature }\end{array}$ \\
\hline \multicolumn{5}{|l|}{ TNFSF11 gene } \\
\hline \multirow{2}{*}{ SNP-290C $>T$} & Forward & GGGAGAGGTTGGACAGGAAG & \multirow{2}{*}{ Dral } & \multirow{2}{*}{16 hours $/ 37^{\circ} \mathrm{C}$} \\
\hline & Reverse & GTCTTTCTGGAGGTCCAAGAGATGGTTTAA & & \\
\hline \multirow{2}{*}{ SNP-643C $>T$} & Forward & TGGTCAGCAACTTCCTTCTG & \multirow{2}{*}{ TspRI } & \multirow{2}{*}{3 hours $/ 65^{\circ} \mathrm{C}$} \\
\hline & Reverse & GACATTCCTCCTGCATCCAT & & \\
\hline \multirow{2}{*}{ SNP-693G $>C$} & Forward & TGGTCAGCAACTTCCTTCTG & \multirow{2}{*}{ BsaJl } & \multirow{2}{*}{3 hours $/ 60^{\circ} \mathrm{C}$} \\
\hline & Reverse & GACATTCCTCCTGCATCCATT & & \\
\hline \multicolumn{5}{|c|}{ TNFRSF11B gene } \\
\hline \multirow{2}{*}{ SNP-163A>G } & Forward & CTGGAGACATATAACTTGAACA & \multirow{2}{*}{ Asel } & \multirow{2}{*}{3 hours $/ 37^{\circ} \mathrm{C}$} \\
\hline & Reverse & CCATCATCAAAGGGCTATTGGT & & \\
\hline \multirow{2}{*}{ SNP-950T>C } & Forward & GTTCCTCAGCCCGGTGGCTTT & \multirow{2}{*}{ Hpal } & \multirow{2}{*}{3 hours $/ 37^{\circ} \mathrm{C}$} \\
\hline & Reverse & TGTGGTCCCCGGAAACCTCAGG & & \\
\hline \multirow{2}{*}{ SNP-1181G>C } & Forward & ACTTCCTGTTGCCGGGACGCTA & \multirow{2}{*}{ Smil } & \multirow{2}{*}{3 hours $/ 55^{\circ} \mathrm{C}$} \\
\hline & Reverse & GGACTTACCACGAGCGCGCAGCACCTCA & & \\
\hline
\end{tabular}




\section{Discussion}

Polymorphisms in low BMD have been investigated worlwide. However, due to the possible influence of race and ethnic factors, new studies on polymorphisms in osteoporosis will still be fascinating and useful. This might be the first study on polymorphism in low BMD in Indonesian women. The results indicated that polymorphisms of the TNFSF11 and TNFRSF11B genes were not associated with low BMD in Indonesian postmenopausal women. This study also did not find any association between SNPs and alleles with low BMD.

\section{Table 2. Characteristics of the participants and bone}

\section{mineral density}

\begin{tabular}{|l|l|}
\hline Characteristics & Mean \pm SD \\
\hline Age (years) & $57.9 \pm 5.31$ \\
\hline Weight $(\mathrm{kg})$ & $57.4 \pm 9.31$ \\
\hline Height $(\mathrm{cm})$ & $149.9 \pm 4.46$ \\
\hline BMI $\left(\mathrm{kg} / \mathrm{m}^{2}\right)$ & $25.5 \pm 3.80$ \\
\hline BMD $\left(\mathrm{g} / \mathrm{cm}^{2}\right)$ & - \\
\hline L1-L4 & $0.91 \pm 0.15$ \\
\hline Femoral neck & $0.75 \pm 0.15$ \\
\hline Total femur & $0.82 \pm 0.14$ \\
\hline $3^{\text {rd }}$ distal radius & $0.67 \pm 0.13$ \\
\hline BMD (T score) & $\mathrm{n}(\%)$ \\
\hline Normal & $10(16.7 \%)$ \\
\hline Low & $50(83.3 \%)$ \\
\hline -Radius & $7(14 \%)$ \\
\hline -L1-L4 & $2(4 \%)$ \\
\hline - 1 sites & $41(82 \%)$ \\
\hline BMD: Bone mineral density, BMl: Body mass index, L: Lumbar \\
\hline
\end{tabular}

Polymorphisms on low BMD has been investigated but the results was less consistent between studies. Race or ethnic, SNPs types, and bone sites might contribute to this. Prior studies on osteoporosis gene polymorphisms had been conducted in postmenopausal women from different race and ethnic including Caucasian, Hispanic and Asian. A study by Vidal et al. (24) involved postmenopausal Caucasian women in Malta and found an association between OPG genes and low BMD. A meta-analysis study by da Silva et al. (25) also found an association between low BMD and SNPs of 163A>G, 950T>C and $1181 \mathrm{G}>\mathrm{C}$ (25). The study of polymorphisms was also conducted in Asia largely in China and Korea (26-29). A study by Sun et al. (26) involving postmenopausal Chinese women suggested that OPG genetic polymorphisms may affect BMD and osteoporosis. Study in postmenopausal Korean women by Kim et al. (28) indicated that OPG gene polymorphisms were related to BMD and osteoporosis. The influence of race and ethnicity on osteoporosis gene polymorphisms was also supported by Wang et al. (30) which investigated RANKL/ RANK/OPG gene polymorphisms and involved five different races and ethnicities including China, Japan, Mongol, African, and Caucasian. Polymorphisms on RANKL/RANK/OPG gene were different among races and ethnic groups. Information on gene polymorphisms in osteoporosis from other race and ethnics are needed. Our study in Indonesian women showed that OPG and RANKL gene polymorphisms had no association with low BMD in postmenopausal women. However, results of our study less conclusive and need further study with larger sample and SNPS.

OPG, RANK, and RANKL gene are the most frequent genes investigated to elucidate the role of polymorphisms in osteoporosis. Prior studies indicated that not all of these gene polymorphisms are proven to be related with BMD

Table 3. The association between allele frequencies and BMD

\begin{tabular}{|c|c|c|c|c|c|c|c|}
\hline TNFSF11 & Genotypes & Healthy & Low BMD & Allele & Healthy & Low BMD & $\mathbf{p}$ \\
\hline \multirow{2}{*}{ SNP $-290 C>T$} & $\mathrm{CC}$ & $1(10 \%)$ & $17(34 \%)$ & $C$ & 10 & 63 & \multirow[t]{2}{*}{$0.28^{*}$} \\
\hline & $\mathrm{CT} / \mathrm{TT}$ & $9(90 \%)$ & $33(66 \%)$ & $\mathrm{T}$ & 10 & 37 & \\
\hline \multirow{2}{*}{ SNP $-643 C>T$} & $C C$ & $2(20 \%)$ & $12(24 \%)$ & $C$ & 11 & 60 & \multirow[t]{2}{*}{$0.62^{*}$} \\
\hline & $\mathrm{CT} / \mathrm{TT}$ & $8(80 \%)$ & $38(76 \%)$ & $T$ & 9 & 40 & \\
\hline \multirow{2}{*}{ SNP -693G>C } & GG & $2(20 \%)$ & $10(20 \%)$ & G & 10 & 54 & \multirow[t]{2}{*}{$0.74^{*}$} \\
\hline & $\mathrm{GC} / \mathrm{CC}$ & $8(80 \%)$ & $40(80 \%)$ & C & 10 & 46 & \\
\hline \multicolumn{8}{|l|}{ TNFRSF11B } \\
\hline \multirow{2}{*}{ SNP $163 A>G$} & AA & $7(70 \%)$ & $36(72 \%)$ & A & 17 & 85 & \multirow[t]{2}{*}{$1.00+$} \\
\hline & AG/GG & $3(30 \%)$ & $14(28 \%)$ & G & 3 & 15 & \\
\hline \multirow{2}{*}{ SNP 950T>C } & TT & $7(70 \%)$ & $29(58 \%)$ & $\mathrm{T}$ & 17 & 78 & \multirow[t]{2}{*}{$0.76+$} \\
\hline & $\mathrm{TC} / \mathrm{CC}$ & $3(30 \%)$ & $21(42 \%)$ & $C$ & 3 & 22 & \\
\hline \multirow{2}{*}{ SNP $1181 \mathrm{G}>C$} & GG & $6(60 \%)$ & $21(42 \%)$ & G & 10 & 69 & \multirow[t]{2}{*}{$0.10^{*}$} \\
\hline & $\mathrm{GC} / \mathrm{CC}$ & $4(40 \%)$ & $29(58 \%)$ & $C$ & 10 & 31 & \\
\hline
\end{tabular}

SNP: Single nucleotide polymorphisms, BMD: Bone mineral density, TNFRSF11B: Tumor necrosis factor receptor superfamily member 11B, TNFSF11: Tumor necrosis factor ligand superfamily member $11,{ }^{*}$ Chi square, +Fischer exact test 
Table 4. The correlation between BMD of bones sites and SNPs

\begin{tabular}{|c|c|c|c|c|c|c|c|c|}
\hline \multirow{2}{*}{ TNFSF11 } & \multicolumn{2}{|c|}{ SNP $-290 C>T$} & \multicolumn{2}{|c|}{ SNP $-643 C>T$} & \multicolumn{2}{|c|}{ SNP $-693 G>C$} & \multirow[t]{2}{*}{ Adjusted R } & \multirow[t]{2}{*}{$p$} \\
\hline & $\boldsymbol{\beta}$ & $p$ & $\boldsymbol{\beta}$ & $\mathbf{p}$ & $\boldsymbol{\beta}$ & $p$ & & \\
\hline L1-L4 & 0.31 & 0.08 & -0.26 & 0.22 & 0.06 & 0.72 & 0.00 & 0.38 \\
\hline Femoral neck & 0.22 & 0.21 & -0.02 & 0.93 & 0.10 & 0.54 & 0.02 & 0.27 \\
\hline Total femur & 0.21 & 0.25 & -0.17 & 0.43 & 0.03 & 0.87 & -0.03 & 0.72 \\
\hline $3^{\text {rd }}$ distal radius & 0.30 & 0.10 & -0.36 & 0.09 & 0.06 & 0.73 & 0.01 & 0.30 \\
\hline \multirow{2}{*}{ TNFRSF11B } & \multicolumn{2}{|c|}{ SNP $163 A>G$} & \multicolumn{2}{|c|}{ SNP 950T>C } & \multicolumn{2}{|c|}{ SNP $1181 \mathrm{G}>C$} & \multirow[t]{2}{*}{ Adjusted R } & \multirow[t]{2}{*}{$p$} \\
\hline & $\beta$ & $p$ & $\beta$ & $p$ & $\beta$ & $\mathrm{p}$ & & \\
\hline L1-L4 & 0.04 & 0.76 & 0.01 & 0.94 & -0.21 & 0.13 & -0.01 & 0.47 \\
\hline Femoral neck & -0.05 & 0.71 & -0.03 & 0.82 & -0.01 & 0.93 & -0.05 & 0.97 \\
\hline Total femur & -0.12 & 0.37 & -0.08 & 0.56 & 0.01 & 0.94 & -0.03 & 0.74 \\
\hline $3^{\text {rd }}$ distal radius & 0.07 & 0.60 & 0.07 & 0.59 & 0.10 & 0.45 & -0.03 & 0.68 \\
\hline
\end{tabular}

and osteoporosis although in the same race and ethnicity. Two meta-analysis studies confirmed the link of OPG gene polymorphisms with BMD and osteoporosis $(31,32)$. A study by Kim et al. (28) showed that among OPG, RANK, and RANKL which were investigated, only OPG had an association with BMD and osteoporosis. A similar result was reported by Shang et al. (33) which involved peri- and postmenopausal women in China. The findings suggested that OPG and RANK but not RANKL genetic polymorphisms influenced BMD in Chinese women. An opposite result was reported by Tu et al. (34) their study illustrated that RANK and RANKL but not OPG gene influence BMD in Chinese postmenopausal women. The recent study examined the association between RANKL and OPG gene polymorphisms, and no association was found. From the results of the studies, which gene polymorphisms are most associated with BMD have not been determined yet and require further confirmation from future studies.

Alleles and genotypes in genes determine the influence of gene polymorphisms on BMD with the effect could be positive or negative. Two meta-analysis study found $G$ allele of the OPG $163 \mathrm{~A}>\mathrm{G}$ polymorphisms increased osteoporosis risk in Caucasians whereas allele $C$ of the OPG $1181 \mathrm{G}>C$ decreased osteoporosis risk mainly in Asians (31,32). A pilot study by Cvijetic showed that postmenopausal women with osteoporosis had AG genotype (of the 163A>G) polymorphism more frequently than women without osteoporosis while the prevalence of TT and GG polymorphism between patients with and without osteoporosis was not significantly different (35). Langdahl et al. (23) reported that in SNP 163A>G, G alleles were more commonly found in subjects with osteoporosis than normal. GG genotypes are also more commonly found in subjects with osteoporosis whereas, in SNP 950T>C, CC genotype was higher in the normal group than in the osteoporosis group (23). Association of 950T>C and osteoporosis was also reported by Li et al. (36) using a meta-analysis study in Chinese. A study by Sun et al. (26) found subjects with genotype TT of the
g.26395T>C and genotype AA of the g.27649A>G genetic polymorphism had a significantly higher BMD when compared with those of genotypes TC and CC and those of genotypes $A G$ and $G G$, respectively. Our study did not find any association between allele and genotype with BMD but G1181C of OPG genes showed the smallest $p$ value $(0.1)$ in which $G G$ genotype and $\mathrm{G}$ allele were more pronounced in low BMD while $\mathrm{GC}$ / CC genotype and $C$ allele were higher in normal. Alleles seems to be more influential on BMD than SNPs in which $G$ allele is associated with susceptibility to low BMD whereas $C$ allele had a protective effect against low BMD

The influence of gene polymorphisms might be specific to bone sites. Piedra et al. (37) reported a relationship between the genotype of SNPs and BMD in patients with primary hyperparathyroidism. Minor homozygote genotype (GG for $163 A>G$ ) had significantly lower BMD in $1 / 3$ distal radius but not for GG for 1181G>C. A study by Tu et al. (34) also illustrated the relationship between polymorphisms and bone sites. The results confirmed that RANK and RANKL gene polymorphisms affect BMD in the femoral neck. Our study found no association between SNP and any bone sites. Analysing distribution of low BMD in each bone site, most of the subjects had low BMD on more than one bone site while there were only little low BMD on single bone site in our subjects. Also, the number of subjects with normal BMD was too low. These may cause a lack of significant association between SNPs and bone sites.

Several risk factors are attributed to low bone mass. Age at menarche, age at menopause, older age, height and BMI have been recognized as risk factors for low BMD (38-40). Age at menarche and at menopause had been known to have a relationship with osteoporosis gene polymorphisms (RANK gene) (41). Influence of other risk factors (age, height, BMI) on polymorphisms in low BMD is not known and thus requires an advanced study.

The important limitation of this study is sample size and SNPs frequency. The study on genomic and polymorphisms requires 
a large number of subjects and SNPs. A small sample and SNPs result in a decrease of statistical power to identify small differences between groups that may exist in this study. Also, the distribution of BMD value between the groups was not comparable. Only $16.7 \%$ of subjects had normal BMD. In addition, as there are many ethnicities and tribes in Indonesia, it is recommended to conduct further studies with larger sample sizes and SNPs among various ethnicities and tribes to obtain a better result.

\section{Conclusion}

In summary, this preliminary study with small sample size did not find any association between OPG and RANK gene polymorphisms with low BMD in Indonesian postmenopausal women aged 50-65 years.

\section{Acknowledgments}

This work was funded by Universitas Katolik Indonesia Atma Jaya. We are very grateful to Safarina G Malik, MS., Ph.D.; Sukma Oktavianthi, B.Sc.; Lidwina Priliani, B.Sc., and all staffs of the Eijkman Institute who gave advice and assistance in laboratory works.

\section{Ethics}

Ethics Committee Approval: The study was approved by the Research Ethics Committee of the Faculty of Medicine, Universitas Indonesia and Cipto Mangunkusumo Hospital (Protocol number: 679/UN2.F1/ETIK/2014).

Informed Consent: All study participants agreed to be involved in the study by signing informed consent forms.

Peer-review: Externally peer-reviewed.

\section{Authorship Contributions}

Concept: I.R.H., Design: I.R.H., H.S., E.I.I., S.W.J., A.P., Data Collection or Process: I.R.H., M.A., Analysis and Interpretation: M.A., I.R.H., E.I.I., A.L., Literature Research: I.R.H., A.P., A.T., S.W.J., H.S., Writing: I.R.H.

Conflict of Interest: The authors declare that there is no conflict of interest in any form.

Financial Support: Universitas Katolik Indonesia Atma Jaya and Directorate General of Higher Education, Ministry of Research,Technology and Higher Education (Simlitabmas).

\section{References}

1. Wade SW, Strader C, Fitzpatrick LA, Anthony MS, O'Malley CD. Estimating prevalence of osteoporosis: examples from industrialized countries. Arch Osteoporos 2014;9:182.

2. Mithal A, Dhingra V, Lau E. The Asian Audit. Epidemiology, costs and burden of osteoporosis in Asia 2009. International Osteoporosis Foundation. https://www.iofbonehealth.org/sites/ default/files/PDFs/Audit\%20Asia/Asian_regional_audit_2009.pdf

3. Population Statistics for Seniors 2013, Central Bureau of Statistics, Jakarta-Indonesia.

4. Data And Osteoporosis Disease Condition in Indonesia. Infodatin Data and Information Center Ministry of Health RI. 2015. https:// www.depkes.go.id. 26th April 2017.

5. Weitzmann MN, Pacifici R. Estrogen deficiency and bone loss: an inflammatory tale. J Clin Invest 2006;116:1186-94.
6. Raggat LJ, Partridge NC. Cellular and molecular mechanisms of bone remodelling. J Biol Chem 2010;285:25103-8.

7. Boyle WJ, Simonet WS, Lacey DL. Osteoclast differentiation and activation. Nature 2003:423:337-42.

8. Liu C, Walter TS, Huang P, Zhang S, Zhu X, Wu Y, et al. Structural and functional insights of RANKL-RANK interaction and signaling. J Immunol 2010;184:6910-9.

9. Martin TJ, Sims NA. How cells communicate in the bone remodelling process. J Korean Endocr Soc 2010;25:1-8.

10. Seremak-Mrozikiewicz A, Barlik M, Drews K, Bogacz A, Tatuśko J, Piotrowska A, et al. The genetic variants of RANKL/RANK/ OPG signal trial in postmenopausal women with osteopenia and osteoporosis. Arch perinatal Med 2011;17:72-80.

11. Klein-Nulend J, Bakker AD, Bacabac RG, Vatsa A, Weinbaum $\mathrm{S}$. Mechanosensation and transduction in osteocytes. Bone 2013:54:182-90.

12. Roshandel D, Holliday KL, Pye SR, Boonen S, Borghs $H$, Vanderschuren D, et al. Genetic variation in the RANKL/RANK/ OPG signaling pathway is associated with bone turnover and bone mineral density in men. J Bone Miner Res 2010;25:1830-8.

13. Takács I, Lazáry Á, Kósa JP, Kiss J, Balla B, Nagy Z, et al. Allelic variations of RANKL/OPG signaling system are related to bone mineral density and in vivo gene expression. Eur J Endocrinol 2010;162:423-31.

14. Cheung CL, Xiao SM, Kung AWC. Genetic epidemiology of age-related osteoporosis and its clinical applications. Nat Rev Rheumatol 2010;6:507-17.

15. Zheng $H$, Wang $C$, He JW, Fu WZ, Zhang ZL. OPG, RANKL, and RANK gene polymorphism and the bone mineral density response to alendronate therapy in postmenopausal Chinese women with osteoporosis or osteopenia. Pharmacogenet Genomics 2016;26:12-9

16. Wolski H, Drews K, Bogacz A, Kamiński A, Barlik M, BartkowiakWieczorek J, et al. The RANKL/RANK/OPG signal trail: significance of genetic polymorphisms in the etiology of postmenopausal osteoporosis. Ginekol Pol 2016;87:347-52.

17. Boroňová I, Bernasovská J, Mačeková S, Petrejčíková E, Tomková Z, Kl'oc J, et al. TNFRSF11B gene polymorphisms, bone mineral density, and fractures in Slovak postmenopausal women. J Appl Genetics 2015;56:57-63.

18. Sassi R, Sahli H, Cheour E, Sellami S, El Gaaied ABA. -643C>T RANKL gene polymorphism is associated with osteoporosis in Tunisian postmenopausal women. Climacteric 2017;20:374-8.

19. Blake GM, Fogelman I. The role of DXA bone density scans in the diagnosis and treatment of osteoporosis. Postgrad Med J 2007;83:509-17.

20. Millar SA, Dykes DD, Polesky HF. A simple salting out procedure for extracting DNA from human nucleated cells. Nucleic Acids Res 1988:16:1215.

21. Mencej S, Prezelj J, Kocijancic A, Ostanek B, Marc J. Association of TNFSF11 gene promoter polymorphisms with bone mineral density in postmenopausal women. Maturitas 2006;55:219-26.

22. Mencej S, Albagha OME, Prezelj J, Kocjan T, Marc J. Tumor necrosis factor superfamily member 11 gene promoter polymorphisms modulate promoter activity and influence bone mineral density in postmenopausal women with osteoporosis. J Mol Endocrinol 2008:40:273-9.

23. Langdahl BL, Carstens M, Stenkjaer L, Eriksen EF. Polymorphisms in the osteoprotegerin gene are associated with osteoporotic fractures. J Bone Miner Res 2002;17:1245-55.

24. Vidal C, Brincat M, Anastasi AX. TNFRSF11B gene variants and bone mineral density in postmenopausal women in Malta. Maturitas 2006;53:386-95.

25. da Silva FRP, Vasconcelos ACCG, Casimiro GS, Pessoa LS, Neto APRN, Vasconcelos DFP. Quantitative assessment of the association between polymorphisms in osteoprotegerin gene and risk of low bone mineral density. Int Arch Med 2015;8:12.

26. Sun $T$, Chen $M$, Lin $X, Y u R$, Zhao $Y$, Wang J. The influence of osteoprotegerin genetic polymorphisms on bone mineral density and osteoporosis in Chinese postmenopausal women. Int Immunopharmacol 2014;22:200-3. 
27. Yu F, Huang X, Miao J, Guo L, Tao D. Association between osteoprotegerin genetic variants and osteoporosis in Chinese postmenopausal women. Endocr J 2013;60:1303-7.

28. Kim JG, Kim JH, Kim JY, Ku SY, Jee BC, Suh CS, et al. Association between osteoprotegerin (OPG), receptor activator of nuclear factor-kappaB (RANK), and RANK ligand (RANKL) gene polymorphisms and circulating OPG, soluble RANKL levels, and bone mineral density in Korean postmenopausal women. Menopause 2007;14:913-8

29. Choi JY, Shin A, Park SK, Chung HW, Cho SI, Shin CS, et al. Genetic polymorphisms of OPG, RANK, and ESR1 and bone mineral density in Korean postmenopausal women. Calcif Tissue Int 2005;77:152-9.

30. Wang J, Wang $Y$, Zhao $Y$, Li $Y$, Sun $M$, Na R, et al. Polymorphisms of genes in the OPG/RANKL/RANK pathway in the Mongols of Inner Mongolia China: relationship to other populations. Int J Clin Exp Med 2016;9:3851-9.

31. Guo L, Tang K, Quan Z, Zhao Z, Jiang D. Association between seven common OPG genetic polymorphisms and osteoporosis risk: a meta-analysis. DNA Cell Biol 2014;33:29-39.

32. Luo Y, Hu Z, Hao J, Jiang W, Shen J, Zhao J. Significant association between the the A163G and G1181C polymorphisms of the osteoprotegerin gene and risk of osteoporosis, especially in postmenopausal women: a meta-analysis. Genet Test Mo Biomarker 2014;18:211-9

33. Shang M, Lin L, Cui $H$. Association of genetic polymorphisms of RANK, RANKL and OPG with bone mineral density in Chinese periand postmenopausal women. Clin Biochem 2013;46:1493-501.

34. Tu $P$, Duan $P$, Zhang RS, Xu DB, Wang $Y$, Wu HP, et al. Polymorphisms in genes in the RANK/RANKL/OPG pathway are associated with bone mineral density at different sites in postmenopausal women. Osteoporosis Int 2015;26:179-85.

35. Cvijetic S, Grazio S, Kosovic P, Uremovic M, Nemcic T, Bobic J. Osteoporosis and polymorphisms of osteoprotegerin gene in postmenopausal women - a pilot study. Reumatologia 2016;54:10-3

36. Li S, Jiang $H$, Du N. Association between osteoprotegerin gene T950C polymorphisms and osteoporosis risk in the Chinese population: evidence via meta-analysis. PloS One 2017; 12:e0189825

37. Piedra M, García-Unzueta MT, Berja A, Paule B, Lavin BA, Raincho JA, et al. Single nucleotide polymorphisms of the OPG/RANKL system genes in primary hyperparathyroidism and their relationship with bone mineral density. BMC Med Genet 2011;12:168.

38. Sioka C, Fotopoulos A, Georgiou A, Xourgia X, Papadopoulos A, Kalef-Ezra JA. Age at menarche, age at menopause and duration of fertility as risk factors for osteoporosis. J Climacteric 2010;13:63-71.

39. Cristina de Sousa E Silva Araujo E, Pagotto V, Silveira EA. Bone Mineral Density in the Noninstitutionalized Elderly: Influence of Sociodemographic and Anthropometric Factors. Curr Gerontol Geriatr Res 2016;2016:4946593.

40. Prastowo NA, Ali S, Haryono IR. A population-based study on bone mineral density using Dual-Energy X-Ray Absorptiometry (DEXA) in postmenopausal women in Jakarta, Indonesia. Int J Osteoporos Metabol Disorder 2018;11:1-6.

41. Duan P, Wang ZM, Liu J, Wang LN, Yang Z, Tu P. Gene polymorphisms in RANKL/RANK/OPG pathway are associated with age at menarche and natural menopaue in Chinese women. BMC Womens Health 2015;15:32. 